\title{
Votes, populism, and pandemics
}

\author{
Alexi Gugushvili ${ }^{1} \cdot$ Jonathan Koltai ${ }^{2} \cdot$ David Stuckler $^{2} \cdot$ Martin McKee $^{3}$
}

Received: 6 July 2020 / Accepted: 6 July 2020 / Published online: 1 August 2020

(c) Swiss School of Public Health (SSPH+) 2020

Seven months into the COVID-19 pandemic, we have learnt something quite unexpected: disease outbreaks can fuel populism, and populism can fuel disease spread (McKee et al. 2020).

The USA, UK, and Brazil are three of the worst affected countries. By early July 2020, the USA had more confirmed COVID-related infections than the combined total in the next three countries with most cases; the UK ranked third globally for confirmed COVID-19 deaths; and Brazil endured the largest number of COVID-related infections and deaths in Southern Hemisphere.

All are led by populist politicians. Brazil's Jair Bolsonaro very visibly distanced himself from restrictions. This mattered. A recent study found that his speeches coincided with increases in people ignoring these restrictions (Ajzenman et al. 2020). Then, he blocked publication of COVID statistics although a Supreme Court judge has since ruled that they must appear. In the UK, Boris Johnson delayed imposing restrictions and boasted about shaking hands 'with everybody' while visiting a COVID ward. And in late May, President Trump blocked the USA's contribution to WHO, plunging the organization into financial turmoil.

Alexi Gugushvili

alexi.gugushvili@sosgeo.uio.no

Jonathan Koltai

jonathan.koltai@unibocconi.it

David Stuckler

david.stuckler@unibocconi.it

Martin McKee

Martin.McKee@1shtm.ac.uk

1 University of Oslo, Postboks 1096 Blindern, 0317 Oslo, Norway

2 Carlo F. Dondena Centre for Research On Social Dynamics and Public Policy, Bocconi University, Via Guglielmo Rontgen, 1, 20136 Milan, Italy

3 London School of Hygiene and Tropical Medicine, 15-17 Tavistock Place, London WC1H 9SH, UK
Populism is often described as pitting the "common sense' of a virtuous people against expert knowledge. It often combines anti-elite, anti-scientific attitudes with preference for 'natives,' or citizens of the same skin color. Its arguments often oppose public health measures that are based on evidence from research.

A growing body of research finds that populism is a risk to population health, and not just during pandemics. One cross-national study found that populist leaders tend to support anti-vaccine views, which correlates with greater levels of vaccine hesitancy (Kennedy 2019). The rise of populism coincides with 'post-truth' politics that can be used to justify discriminatory policies that harm the health of marginalized groups. Following the UK's decision to leave the EU, widely considered a populist outcome, health scholars warned that the decision would have profound and far-reaching implications for the health of the British population, with leading medical journals and public health organizations united in calling for a second vote or opposing it 'as a whole' (Kmietowicz 2018; The Lancet 2018).

Historically, populist leaders may have benefited when health of their populations deteriorates. Influenza deaths among German municipalities in 1918 were correlated with increases in the share of votes won by extremist parties, such as the National Socialist Workers Party (Nazi Party), in the 1932 and 1933 elections (Blickle 2020). Although the world is different from what it was a century ago in myriad ways, studies have also linked rising mortality and declining life expectancy to recent gains for populists at the ballot box. One study found that increases in 'deaths of despair' - mortality related to suicide or drug poisoning correlated with the geographical distribution of votes to leave the EU in the 2016 Brexit referendum (Koltai et al. 2020). Another study found that those counties in which life expectancy stagnated or declined from 1980 to 2014 were more likely to swing toward Trump in the 2016 US presidential election (Bor 2017). While the exact mechanisms driving these associations are unknown, it has been suggested that worsening population health may be an 
indicator of broader social suffering and discontent, with groups in the population that are being left behind creating fertile ground for the growth of populist sentiments (Gugushvili 2020).

Future electoral outcomes, including in countries previously immune from widespread populism, may be influenced by the extent to which governments are able to mitigate the suffering that has resulted from the pandemic, especially where communities have been weakened by earlier austerity. Those municipalities worst affected by austerity in the 1930s saw the greatest electoral gains by the Nazi party in Germany (Galofré-Vilà et al. 2019), while communities experiencing deeper austerity were also those most likely to vote for Brexit (Fetzer 2019).

Populist leaders will be tempted to exploit the crisis for political gain. President Trump's use of the term 'Chinese virus' feeds into a populist narrative in which stories are promulgated that Chinese authorities intentionally bred the virus in laboratories and people of East Asian appearance are being attacked. Yet at the same time, many people are recognizing the contribution that those from black and minority ethnic communities are making to essential services, such as health and social care, and are encouraging a sense of solidarity. We cannot know which view will prevail, but we can at least add our voices to those who seek to unite rather than divide us.

Acknowledgment Not applicable.

Authors' contributions All authors contributed equally.

Funding Not applicable.

Availability of data and materials Not applicable.

\section{Compliance with ethical standards}

Conflict of interest The authors declare that they have no conflict of interests.
Ethics approval Not applicable.

Informed consent Not applicable.

\section{References}

Ajzenman N, Cavalcanti T, Mata D Da (2020) More than Words: Leaders' Speech and Risky Behavior During a Pandemic. São Paulo

Blickle K (2020) Pandemics Change Cities: Municipal Spending and Voter Extremism in Germany, 1918-1933. New York

Bor J (2017) Diverging Life Expectancies and Voting Patterns in the 2016 US Presidential Election. Am J Public Health 107:1560-1562. https://doi.org/10.2105/AJPH.2017.303945

Fetzer T (2019) Did austerity cause brexit? Am Econ Rev 109:3849-3886. https://doi.org/10.1257/aer.20181164

Galofré-Vilà G, Meissner CM, McKee M, Stuckler D (2019) Austerity and the rise of the Nazi party. NBER Work Pap 24106:1-43

Gugushvili A (2020) A population health perspective on the trump administration, Brexit, and right-wing populism in Europe. Am J Public Health 110:274-276. https://doi.org/10.2105/AJPH.2019. 305535

Kennedy J (2019) Populist politics and vaccine hesitancy in Western Europe: an analysis of national-level data. Eur J Public Health 29:512-516. https://doi.org/10.1093/eurpub/ckz004

Kmietowicz Z (2018) BMA votes to oppose Brexit "as a whole" and calls for public final say on deal. BMJ k2821. https://doi.org/10. 1136/bmj.k2821

Koltai J, Varchetta FM, McKee M, Stuckler D (2020) Deaths of despair and Brexit votes: cross-local authority statistical analysis in england and wales. Am J Public Health 110:401-406. https:// doi.org/10.2105/AJPH.2019.305488

Lancet The (2018) High noon for a sensible decision on Brexit. Lancet 392:1599. https://doi.org/10.1016/S0140-6736(18)327685

McKee M, Gugushvili A, Koltai J, Stuckler D (2020) Are populist leaders creating the conditions for the spread of COVID-19? comment on "A scoping review of populist radical right parties' influence on welfare policy and its implications for population health in Europe”. Int J Heal Policy Manag. https://doi.org/10. 34172/ijhpm.2020.124

Publisher's Note Springer Nature remains neutral with regard to jurisdictional claims in published maps and institutional affiliations. 